\title{
TATA CARA PELAKSANAAN PENANGGUHAN PENAHANAN TERHADAP TERSANGKA DI LEMBAGA KEPOLISIAN BERDASARKAN KUHAP DAN PERATURAN PELAKSANAANNYA
}

\author{
Oleh : \\ Umi Enggarsasi \\ Atet Sumanto
}

\begin{abstract}
Detention pursuant to KUHAP is location or certain defendant in place by Investigator or publik prosecutor or Judge with its stipulating, while reason to source the detention as arranged in Section 21 KUHAP mentioned that detention can be with the consideration for example, defendant felt concerned about to break away, defendant felt concerned about will destroy/eliminating evidence goods, and, defendant felt concerned about will again doing an injustice. defendant can ask the detention deferment based on Section 31 KUHAP to police detention with the guarantee of money or people or on trust pursuant to condition determined, while such condition determined that is obliged to report, do not go out the house or town, and a period oto detention deferment from defendant do not the inclusive of a period to prisoner status as arranged in KUHAP.
\end{abstract}

Keyword : Detention, Legal Fundament Of Detention Deferment, Procedure Of Executor OfDetention Deferment

\section{PENDAHULUAN}

Kitab Undang-Undang Hukum Acara Pidana (selanjutnya disebut KUHAP) mengatur tentang hak dan kewajiban para pelaksana penegak hukum. Mereka memikul tugas dan tanggungjawab sesuai undang-undang yaitu menegakkan hukum, khususnya Hukum Acara Pidana.

Keberadaan KUHAP menghendaki perubahan sikap dan orientasi dalam cendekatan terhadap tugas penegak hukum, penegak hukum tidak lagi berorientasi pada penonjolan kekuasaan, melainkan pada kepentingan nasional yang lebih tinggi, yaitu melalui penegakan hukum mendidik warga Negara agar mampu menghayati kewajiban dan hak yang diberikan oleh hukum serta berani memperjuangkan harkat martabatnya sebagai umat manusia.

Polisi sebagai salah satu aparat penegak hukum merupakan pejabat Negara Republik Indonesia yang mempunyai tugas sebagaimana diatur dalam KUHAP, yaitu sebagai penyidik, penyidik pembantu, dan penyelidik,
Tata Cara Pelaksanaan Penangguhan

Penahanan Terhadap Tersangka Di

Lembaga Kepolisian Berdasarkan KUHAP

Dan Peraturan Pelaksanaannya
416

Umi Enggarsasi Atet Sumanto 
apabila bertugas sebagai penyidik akan melakukan serangkaian tindakan untuk mencari serta mengumpulkan barang bukti, dan untuk menemukan tersangkanya, sedangkan polisi sebagai penyelidik untuk mencari dan menemukan suatu peristiwa yang diduga sebagai tindak pidana guna menentukan dapat atau tidaknya dilakukan penyidikan menurut cara yang diatur dalam KUHAP. Selain diatur dalam Undang-Undang Nomor 8 Tahun 1981, mengenai tugas kepolisian diatur pula dalam Undang-Undang Nomor 2 Tahun 2002 tentang Kepolisian Negara Republik Indonesia yang merupakan perubahan Undang-Undang Nomor 28 Tahun 1997 tentang Kepolisian Negara Republik Indonesia yang sudah tidak memadai dan perlu diganti untuk disesuaikan dengan pertumbuhan dan perkembangan hukum serta Ketatanegaraan Republik Indonesia.

Perubahan ketatanegaraan yang diikuti dengan keluarnya Undang-Undang Nomor 2 Tahun 2002 dengan pertimbangan bila keamanan dalam negeri merupakan syarat utama mendukung terwujudnya masyarakat madani yang adil, makmur dan beradab berdasarkan Pancasila dan Undang-Undang Dasar Republik Indonesia
Tahun 1945, selain itu ke-beradaan kepolisian dimaksudkan untuk pemeliharaan keamanan dalam Negara melalui upaya penyelenggaraan fungsi kepolisian yang meliputi pemeliharaan keamanan dan ketertiban masyarakat, penegakan hukum, perlindungan, pengayoman dan pelayanan kepada masyarakat selaku alat Negara yang dibantu oleh masyarakat dengan menjunjung tinggi hak asasi manusia.

$$
\text { kota-kota besar di Indonesia }
$$
mempunyai perkembangan pesat di segala bidang yang berdampak maraknya berbagai aksi kejahatan yang dilakukan oleh berbagai golongan masyarakat baik yang dilakukan oleh masyarakat yang golongan ekonominya tingkat bawah maupun masyarakat dengan golongan ekonomi menengah ke atas. Dengan kondisi yang demikian polisi dituntut bekerja keras untuk melakukan tindakan pemberantasan. Berbekal kewenangan yang ada polisi dapat melakukan penangkapan dan penahanan terhadap pihak yang dicurigai melakukan kejahatan.

Penahanan berdasarkan KUHAP adalah penempatan tersangka atau terdakwa di tempat tertentu oleh Penyidik atau penuntut Umum atau Hakim dengan
Tata Cara Pelaksanaan Penangguhan Penahanan Terhadap Tersangka Di Lembaga Kepolisian Berdasarkan KUHAP Dan Peraturan Pelaksanaannya 
penetapannya, sedangkan alasan untuk melakukan penahanan sebagaimana diatur dalam Pasal 21 KUHAP disebutkan bahwa penahanan dapat dilakukan dengan pertimbangan antara lain

1. Tersangkalterdakwa dikhawatirkan melarikan diri;

2. Tersangka/terdakwa dikhawatirkan akan merusaklmenghilangkan barang bukti, dan

3. Tersangka/terdakwa dikhawatirkan akan melakukan lagi tindak pidana.

Untuk melaksanakan penahanan terhadap tersangka/terdakwa tersebut harus diserahkan kepada tersangka/ terdakwa juga kepada maka petugas harus dilengkapi dengan surat perintah penahanan dan sewaktu akan melaksanakan penahanan surat perintah penahanan kewarganya.

Tersangka/terdakwa dapat minta penangguhan penahanan berdasar Pasal 31 KUHAP kepada aparat yang melakukan penahanan dengan jaminan uang atau orang atau tanpa jaminan berdasarkan syarat yang ditentukan, sedangkan yang dimaksud syarat yang ditentukan yaitu wajib lapor, tidak keluar rumah atau kota, dan masa penangguhan penahanan dari seorang tersangka/ terdakwa tidak termasuk masa status tahanan sebagaimana diatur dalam KUHAP.

\section{RUMUSAN MASALAH}

Berdasarkan latar belakang masalah tersebut, dapat dirumuskan beberapa permasalahan sebagai berikut: Bagaimana tata cara pelaksanaan penangguhan penahanan terhadap tersangka di lembaga kepolisian berdasarkan KUHAP dan peraturan pelaksanaan lainnya

\section{PEMBAHASAN}

\section{Latar Belakang Permohonan Pe- nangguhan Penahanan}

Permohonan Penangguhan Penahanan biasanya dilatarbelakangi adanya kesepakatan antara kedua belah pihak baik pelapor maupun terlapor. Kesepakatan yang dilakukan dengan disaksikan oleh instansi yang berwenang. Selain itu delik yang terjadi berupa delik aduan sehingga memungkinkan dihentikan oleh pihak pengadu. Hal ini sesuai pengertian pengaduan yang diatur dalam Pasal 1 angka 25 KUHAP bahwa pengaduan adalah pemberitahuan 
melakukan penahanan sebagaimana diatur dalam Pasal 21 KUHAP disebutkan bahwa penahanan dapat dilakukan dengan pertimbangan antara lain

1. Tersangkalterdakwa dikhawatirkan melarikan diri;

2. Tersangka/terdakwa dikhawatirkan akan merusaklmenghilangkan barang bukti, dan

3. Tersangka/terdakwa dikhawatirkan akan melakukan lagi tindak pidana.

Untuk melaksanakan penahanan terhadap tersangka/terdakwa tersebut harus diserahkan kepada tersangka/ terdakwa juga kepada maka petugas harus dilengkapi dengan surat perintah penahanan dan sewaktu akan melaksanakan penahanan surat perintah penahanan kewarganya.

Tersangka/terdakwa dapat minta penangguhan penahanan berdasar Pasal 31 KUHAP kepada aparat yang melakukan penahanan dengan jaminan uang atau orang atau tanpa jaminan berdasarkan syarat yang ditentukan, sedangkan yang dimaksud syarat yang ditentukan yaitu wajib lapor, tidak keluar rumah atau kota, dan masa penangguhan penahanan dari seorang tersangka/ terdakwa tidak termasuk masa status tahanan sebagaimana diatur dalam KUHAP.

\section{RUMUSAN MASALAH}

Berdasarkan latar belakang masalah tersebut, dapat dirumuskan beberapa permasalahan sebagai berikut: Bagaimana tata cara pelaksanaan penangguhan penahanan terhadap tersangka di lembaga kepolisian berdasarkan KUHAP dan peraturan pelaksanaan lainnya

\section{PEMBAHASAN}

\section{Latar Belakang Permohonan Pe- nangguhan Penahanan}

Permohonan Penangguhan Penahanan biasanya dilatarbelakangi adanya kesepakatan antara kedua belah pihak baik pelapor maupun terlapor. Kesepakatan yang dilakukan dengan disaksikan oleh instansi yang berwenang. Selain itu delik yang terjadi berupa delik aduan sehingga memungkinkan dihentikan oleh pihak pengadu. Hal ini sesuai pengertian pengaduan yang diatur dalam pasal 1 angka 25 KUHAP bahwa pengaduan adalah pemberitahuan 
disertai permintaan oleh pihak yang berkepentingan kepada pejabat yang berwenang untuk menindak menurut hukum seorang yang telah melakukan tindak pidana aduan yang merugikannya.

Kesepakatan untuk penyelesaian tindak pidana tidak ada dalam hukum pidana, namun terhadap delik aduan dimungkinkan sebagaimana tersurat dalam pengertian delik aduan. Apabila kita analisis kata "permintaan" oleh pihak yang berkepentingan menunjukkan hak dari pihak pengadu untuk meneruskan atau tidak kasus tersebut. (S. R Sianturi, 1989 : 241).

Pengertian delik aduan maka pemrosesan perkara tersebut tergantung pada pihak korban. Dengan demikian terhadap perkara delik aduan dimungkinkan terjadi kesepakatan damai pihak pelaku dan pihak korban sehingga kondisi tersebut sebagai salah satu latar belakang terjadinya permohonan penangguhan penahanan. Selain itu di lembaga menerima permohonan penangguhan penahanan dengan latar belakang antara lain :

a.tersangka menderita sakit/ mengalami gengguan jiwa;

b. pertimbangan kemanusiaan; c. adanya jaminan/penjamin.

Tersangka pada waktu diperiksa pihak terkait harus memberikan keterangan yang sebenar-benamya dan tidak terpengaruh faktor apapun juga. Oleh karena itu harus didukung kondisi yang sempuma/sehat baik fisik maupun psikisnya karena apabila kondisinya sakit tersangka berhak minta pemeriksaan ditunda dan mengajukan penangguhan penahanan guna pemeriksaan kesehatan maupun dilakukan perawatan atas derita yang dialami sampai kondisinya layak dilakukan pemeriksaan kembali. Selain itu profesi/kegiatan tersangka juga bisa digunakan sebagai latar belakang lainnya untuk permohonan penangguhan penahanan. Profesi tersangka yang tidak bisa tergantikan orang lain dan juga kebutuhan masyarakat atas keberadaannya yang harus ada merupakan faktor yang bisa digunakan dan dikabulkannya penangguhan penahanan dengan pertimbangan kemanusiaan yang mengharuskan pihak terkait mengabulkan permohonan penangguhan penahanan.

Terkabulnya permohonan penangguhan penahanan selain berlatar belakang faktor kondisi tersangka baik fisik maupun psikisnya, kesepakatan para
Tata Cara Pelaksanaan Penangguhan Penahanan Terhadap Tersangka Di Lembaga Kepolisian Berdasarkan KUHAP Dan Peraturan Pelaksanaannya 
pihak, dan jenis tindak pidananya, selalu diikuti dengan faktor adanya jaminan/ penjamin dari pihak keluarganya atau pendukung permohonan penangguhan penahanan. Faktor jaminan/penjamin dapat berupa sejumlah uang tertentu yang menjadi kesepakatan pihak pemohon dan instansi yang menahannya, dapat juga berupa jaminan orang atas selalu hadirnya pihak tersangka pada waktu dibutuhkan pihak terkait untuk melakukan pemeriksaan.

\section{Syarat dan Jaminan Permohonan Penangguhan Penahanan}

Penahanan atas diri tersangka/ terdakwa dapat ditangguhkan pelaksanaannya oleh Penyidik, Penuntut Umum atau Hakim yang menahannya sesuai dengan kewenangan masing-masing. Penangguhan penahanan itu dilakukan dengan jaminan uang atau orang atau tanpa jaminan sama sekali (Pasal 31 KUHAP).

Untuk itu ditentukan syarat-syarat, seperti:
a. Wajib lapor;
b. Tidak boleh keluar rumah; atau
c. Tidak boleh keluar kota.

Masa penangguhan penahanan ini tidak termasuk masa status tahanan, oleh karena itu tidak dipotongkan dalam hukuman yang dijatuhkan kemudian. Penangguhan penahanan itu sewaktuwaktu dapat dicabut oleh Penyidik atau Penuntut Umum atau oleh Hakim, karena jabatannya; apabila tersangka/terdakwa melanggar syarat yang telah ditentukan (Pasal 31 ayat 2 KUHAP).

Penangguhan penahanan dapat diberikan dengan jaminan orang, uang atau tanpa jaminan sama sekali. Untuk itu akan dibahas penangguhan penahanan dengan jaminan uang atau orang.

\section{a. Jaminan Uang}

Penangguhan penahanan atas diri Tersangka/Terdakwa dengan jaminan uang, maka besarnya uang jaminan itu ditetapkan oleh Pejabat yang berwenang, sesuai dengan tingkat pemeriksaan (Pasal 35 (1) PPRI No. 27/1983). Pejabat yang berwenang, yang dimaksud oleh pasal tersebut adalah:

1. Penyidik di tingkat Penyidikan;

2. Penuntut Umum di Tingkat Penuntutan, dan

3. Hakim di tingkat pemeriksaan di Pengadilan;
Tata Cara Pelaksanaan Penangguhan Penahanan Terhadap Tersangka Di Lembaga Kepolisian Berdasarkan KUHAP Dan Peraturan Pelaksanaannya 
Uang jaminan itu disimpan di Kepaniteraan Pengadilan Negeri dan apabila tersangka/terdakwa melarikan diri dan setelah lewat tiga bulan tidak diketemukan, maka uang jaminan itu menjadi milik Negara dan disetor ke Kas Negara.

Bila setelah setelah lewat waktu tiga bulan Tersangka/Terdakwa tertangkap kembali, maka uang jaminan itu tidak dapat diminta kembali olehnya. Akan tetapi bagi tersangka/terdakwa yang tidak melarikan maka apabila perkaranya telah selesai maka uang jaminan itu dikembalikan kepadanya.

Di dalam praktiknya sering kali uang jaminan yang dimaksud bukannya diserahkan di Kepaniteraan Pengadilan Negeri, tetapi langsung di serahkan kepada instansi yang menahan Tersangka/Terdakwa, baik itu Penyidik ataupun penuntut umum. (Darwan Prinst, 2002:62-63)

Keputusan Menteri Kehakiman RI No : M. 14-PW.07.03 Tahun 1983, tanggal 10 Desember butir 8, mengatur tentang Penangguhan Penahanan dengan jaminan sebagai berikut:

1. Dalam hal ada permintaan untuk penangguhan penahanan yang dikabulkan, maka diadakan perjanjian antara pejabat yang berwenang sesua; dengan tingkat pemeriksaan dengan tersangka atau penasihat hukumnya beserta syarat-syaratnya;

2. Apabila jaminan itu berupa uang, maka uang jaminan harus secara jelas disebutkan dalam perjanjian dan besamya ditetapkan oleh pejabat yang berwenang (Pasal 35 ayat (1) Peraturan Pemerintah Nomor 27 Tahun 1983);

3. Dalam hal jaminan itu adalah orang, maka identitas orang yang menjamin tersebut secara jelas dicantumkan dalam perjanjian dan juga ditetapkan besamya uang yang harus ditanggung oleh penjamin tersebut (Pasal 36 ayat (1) PP Nomor 27 tahun1983);

4. Uang jaminan dimaksud butir 2, disetorkan sendiri oleh pemohon atau penasihat hukumnya atau keluarganya kepaniteraan peng-adilan dengan formulir penyetoran yang dikeluarkan oleh pejabat yang berwenang sesuai dengan tingkat pemeriksaan;

5. Bukti setoran dibuat rangkap tiga,
Tata Cara Pelaksanaan Penangguhan

Penahanan Terhadap Tersangka Di

Lembaga Kepolisian Berdasarkan KUHAP

Dan Peraturan Pelaksanaannya 
sehelai sebagai arsip panitera, sehelai dibawa oleh yang menyetorkan untuk digunakan sebagai bukti telah melaksanakan perjanjian dan yang sehelai lagi dikirimkan oleh Panitera kepada Pejabat yang berwenang melalui kurir, tetapi tidak dititipkan kepada yang menyetorkan, untuk digunakan sebagai alat control;

6. Berdasarkan tanda buktr penyetoran uang yang diperlihatkan oleh keluarga atau kuasanya, atau berdasarkan tanda bukti penyetoran uang jaminan yang diterima dan Panitera pengadilan, atau surat jaminan dan penjamin dalam hal jaminannya adalah orang, maka pejabat yang berwenang sesuai dengan tingkat pemeriksaan mengeluarkan surat perintah /penetapan penangguhan penahanan;

7. Apabila berkas perkara telah diserahkan kepada penuntut umum dan penuntut umum berpendapat bahwa berkas perkara sudah lengkap, sedangkan tersangka masih dalam status penangguhan penahanan dengan jaminan, maka sebelum penyidik mengeluarkan perintah penghentian penangguhan penahanan, agar dikonsultasikan dengan pihak penuntut umum guna mempertimbangkan kelanjutan ditingkat penuntutan;

8. Demikian pula halnya apabila berkas perkara oleh Penuntut Umum telah dilimpahkan kepada pengadilan, sedangkan terdakwa masih status penangguhan penahanan dengan jaminan maka Penuntut umum dalam surat pelimpahannya minta kepada Ketua Pengadilan Negeri agar penangguhan penahanan dengan jaminan tetap dilanjutkan;

9. Dalam hal tersangka/terdakwa melarikan din dan tidak dapat diketemukan lagi, maka diperlukan penetapan pengadilan tentang pengambil alihan uang jaminan tersebut menjadi milik Negara dan memérintahkan kepada Panitera untuk menyetorkan uang tersebut ke Kas Negara;

10. Dalam hal Tersangka/Terdakwa yang dimaksud butir 9 , jaminannya adalah orang, dan temyata penjamin tidak dapat membayar uang yang menjadi tanggungannya maka untuk memenuhi uang jaminan itu, perlu 
penetapan pengadilan untuk melakukan penyitaan terhadap barang-barang milik penjamin menurut Hukum Acara Perdata.

\section{b. Jaminan Orang}

Penangguhan penahanan dengan jaminan orang, maka yang menjadi penjamin dalam hal ini sebaiknya adalah keluarga dekat dari tersangka/terdakwa sendiri, seperti: Orang tua, anak, isteri, suami dan lain-lain. Hal ini guna menghindarkan din dari ancaman Pasal 221 KUHP, apabila kemudian temyata tersangka / terdakwa melarikan diri (Pasal 221 (1) KUHP). Demikian juga Penasihat Hukum dari tersangka/terdakwa hendaknya tidak menjadi penjamin, karena is tidak kebal terhadap ketentuan Pasal 221 KUHP itu, dan pula demi menjaga netralitas Penasihat Hukum itu sendiri. (Darwan Prinst, 2002 :11)

Dalam hal jaminan adalah orang, maka apabila tersangka/terdakwa melarikan diri, maka setelah lewat waktu tiga bulan tidak dapat ditangkap kembali, penjamin wajib membayar sejumlah uang yang jwnlahnya ditentukan oleh pejabat yang berwenang, sesuai dengan tingkat pemeriksaan (Pasal 36 PP RI Nomor 27 tahun1983).

Uang itu harus disetorkan ke Kas Negara melalui Panitera Pengadilan Negeri. Apabila penjamin tidak dapat membayar sejumlah uang yang ditetapkan itu, maka Juru Sita menyita barang miliknya untuk dijual lelang dan hasilnya disetor ke Kas Negara melalui Panitera Pengadilan Negeri. Dalam praktik adakalanya uang jaminan ini tidak diserahkan kepada panitera pengadilan sebagai titipan, akan tetapi diserahkan kepada pejabat yang bersangkutan. (Darwan Prinst, $2002: 11$ ).

d. Tata Cara Pengeluaran Tahanan Karena Penangguhan Penahanan

Mengenai tata cara pengeluaran tahanan karena penangguhan penahan-an diatur dalam Pasal 25 Peraturan Menteri Kehakiman Nomor M.04.UM. 01.06/1983. Lengkapnya bunyi Pasal 25 tersebut:

1. Pengeluaran tahanan karena penangguhan penahanan harus berdasarkan surat perintah pengeluaran tahanan dari instansi yang menahan.
Tata Cara Pelaksanaan Penangguhan Penahanan Terhadap Tersangka Di Lembaga Kepolisian Berdasarkan KUHAP Dan Peraturan Pelaksanaannya 
2. Dalam pembebasan tahanan dimaksud petugas Rutan harus:

a. meneliti surat perintah pengeluaran tahanan dari instansi yang menahan.

b. Membuat berita acara pengeluaran tahanan dari Rutan, dan menyampaikan tembusan kepada instansi yang menahan.

c. Mencatat surat-surat penangguhan penahanan dan mengambil cap sidik jari, tiga jari tengah dari tangan kiri tahanan yang bersangkutan ke dalam register yang disediakan:

d. Memeriksa kesehatan tahanan kepada dokter Rutan, dan menyampaikan kepada instansi yang menahan dan kepada tahanan.

e. Menyerahkan barang-barang milik tahanan yang ada dan dititipkan kepada Rutan dengan berita acara dan mencatat dalam register yang disediakan.

Pengeluaran tahanan selalu ada kerjasama satu instansi dengan instansi lainnya yang mempunyai kewenangan melakukan penahanan yang selalu diikuti penyerahan berkas dengan kelanjutan penahanannya.
Umparnanya pada tingkat pemeriksaan penyidikan, penyidik memberi penangguhan penahanan terhadap tersangka. Kemudian berkas perkara diserahkan penyidik kepada penuntut umum.

Bagaimana kelanjutan penangguhan penahanan tersangka yang diberikah penyidik? Apakah dengan penyerahan berkas perkara dan penyidik kepada penuntut umum dengan sendirinya gugur atau berlanjut? Hal yang seperti ini menjadi pertanyaan pula antara penuntut umum dengan Pengadilan Negeri. Apakah penangguhan penahanan yang diberikan penuntut umum kepada terdakwa akan terhenti apabila penuntut umum melimpahkan perkara kepada Pengadilan Negeri?

Sebenamya hubungan penyerahan perkara dengan status penangguhan penahanan tidak diatur dalam KUHAP maupun dalam PP Nomor 27 tahun1983. hal ini lebih lanjut diatur dalam angka 8 huruf $g$ dan $h$. Lampiran Keputusan Menteri Kehakiman Nomor M.14. PW.07.03/ 1983, yang memberi petunjuk, bagaimana cara pendekatan dan pelaksanaan yang sebaiknya harus
Tata Cara Pelaksanaan Penangguhan Penahanan Terhadap Tersangka Di Lembaga Kepolisian Berdasarkan KUHAP Dan Peraturan Pelaksanaannya 
ditempuh antara instansi penegak hukum dalam penentu-an status penangguhan penahanan apabila berkas perkara diserahkan dari instansi yang memberikan penangguhan kepada instansi lain.(Harahap M. Yahya, 2002 : 224-225)

Mengenai penyerahan berkas perkara dapat terjadi sebagai berikut:

\section{a. Penyidik berkonsultasi dengan Penuntut Umum}

Lampiran Keputusan Menteri Kehakiman No. 14. PW.07.03/1983 angka 8 huruf g: "Apabila berkas perkara telah diserahkan kepada penuntut umum dan penuntut umum berpendapat bahwa berkas perkara sudah lengkap, sedangkan tersangka masih dalam status penangguhan penahanan dengan jaminan maka sebelum penyidik mengeluarkan perintah penghentian penangguhan, agar dikonsultasikan dengan pihak penuntut umum guna mempertimbangkan kelanjutan di tingkat penuntutan".

Konsultasi diperlukan sehubungan dengan batas kewenangan penahanan yang diberikan undang-undang kepada setiap instansi aparat penegak huku:
Pembatasan kewenangan penahanan membawa konsekuensi pertanggungjawaban yuridis atas penahanan. Setiap "peralihan tingkat pemeriksaan", dengan sendirinya menurut hukum mengakibatkan tanggalnya kewenangan dan pertanggungjawaban yuridis" atas penahanan. Berarti dengan penyerahan berkas perkara dari tangan penyidik kepada penuntut umum, dengan sendirinya telah terjadi "peralihan" tingkat pemeriksaan dari tahap penyidikan kepada taraf tingkat penuntutan, dan sekaligus peralihan tingkat pemeriksaan diikuti pula dengan peralihan tanggung jawab yuridis atas penahanan. Seandainya pada tingkat pemeriksaan penyidikan, penyidik memberi penangguhan penahanan kepada tersangka, kewenangan dan tanggung jawab yuridis atas status penangguhan penahanan akan tanggal dan berakhir" setelah penyidik meyerahkan berkas perkara kepada penuntut umum. Oleh karena itu sesuatu yang wajar apabila instansi penyidik sebelum mengirimkan berkas perkara "mengeluarkan perintah penghentian" atau pencabutan penangguhan penahanan yang diberikannya. Demikian yang paling tepat, agar penyidik tidak
Tata Cara Pelaksanaan Penangguhan Penahanan Terhadap Tersangka Di Lembaga Kepolisian Berdasarkan KUHAP Dan Peraturan Pelaksanaannya 
tersangkut lagi atas jaminan yang ditetapkan dalam surat perjanjian penangguhan penahanan yang dibuatnya dengan tersangka atau dengan orang yang menjamin.

Akan tetapi, rupanya cara yang seperti itu tidak dikehendaki oleh angka 8 huruf g Lampiran Keputusan Menteri Kehakiman No.M.14.PW.07.03/1983. Yang dikehendaki ketentuan ini adalah: sebelum penyidik mengeluarkan perintah penghentian penangguhan penahanan, agar dikonsultasikan lebih dulu dengan pihak penentuan umum guna mempertimbangkan kelanjutan penangguhan penahanan dalam tingkat penuntutan. Dari hasil konsultasi, diambil sikap dan keputusan tentang status penangguhan penahanan selanjutnya. Jika penuntut umum sependapat dengan saran penyidik untuk mengakhiri penangguhan, barulah instansi penyidik mengeluarkan surat perintah penghentian penangguhan, dan tindakan penyidikan itu akan dibarengi serta merta dengan surat perintah penahanan oleh instansi penuntut umum. Sebaliknya, jika penuntut umum menyetujui status penangguhan penahanan yang diberikan penyidik pada tingkat pemeriksaan penyidikan, berarti pe- nangguhan penahanan dapat dilanjutkan penuntut umum dalam tingkat penuntutan.

Hasil konsultasi antara penyidik dengan penuntut umum terdapat konsensus untuk melanjutkan penangguhan penahanan yang diberikan instansi penyidik pada tingkat pemeriksaan penyidikan, apakah surat perjanjian penangguhan penahanan perlu lagi diperrbarui antara orang yang bersangkutan dengan pihak penuntut umum? Memang perlu diperbarui atau sekurang-kurangnya dibuat pernyataan bersama antara orang yang bersangkutan dengan pihak penuntut umum yang berisi "persetujuan untuk meianjutkan isi perjanjian penangguhan" yang dibuat oleh penyidik pada taraf pemeriksaan penyidikan. Pembaruan atau pembuatan persetujuan bersama ini sesuai dengan permintaan. Kewenangan pertanggungjawaban yuridis atas penahanan pada setiap peralihan tingkat pemeriksaan. Sesuai dengan asas ini, dengan beralihnya tingkat pemeriksaan ke tangan penuntut umum, gugur kewenangan dan pertanggungjawaban yuridis dari tangan penyidik balk mengenai penahanan maupun penangguhan penahanan.
Tata Cara Pelaksanaan Penangguhan Penahanan Terhadap Tersangka Di Lembaga Kepolisian Berdasarkan KUHAP Dan Peraturan Pelaksanaannya 
Berarti dari segi yuridis, perjanjian penangguhan penahanan yang dibuat antara tersangka dengan pihak penyidik tidak mempunyai kekuatan hukum lagi pada tingkat penuntutan. Oleh karena itu, jika status penangguhan penahanan yang diberikan penyidik akan dilanjutkan dalam tingkat penuntutan oleh penuntut umum, harus didasarkan atas perjanjian penangguhan penahanan yang baru antara orang yang bersangkutan dengan pihak penuntut umum. Atau sekurang-kurangnya pembaruan itu dituangkan dalam surat pernyataan bersama antara mereka. tanpa pembaruan surat perjanjian, penangguhan semula tidak sah dan tidak mempunyai kekuatan hukum dalam tingkat penuntutan. Karena itu penangguhan itu pun dianggap tidak sah, sebab didasarkan atas tindakan penyidik yang sudah berada di luar kewenangannya. Oleh karena itu persetujuan semula harus dituangkan dalam bentuk perjanjian baru dengan jalan "novasin. (Harahap M. Yahya, 2002 : 226-227)

\section{b. Penuntut Umum Meminta Ketua Pengadilan Negeri Penangguhan Dilanjutkan}

Kelanjutan penangguhan pe- nahanan antara instansi penuntut umum kepada Pengadilan Negeri, dasar-dasar pemikiran yang diuraikan pada peralihan kelanjutan penangguhan penahanan antara instansi penyidik dengan pihak penuntut umum, serupa hal dan asasnya dalam peralihan kelanjutan penangguhan antara penuntut umum dengan Pengadilan Negeri.

Oleh karena itu, sepanjang mengenai landasan pemikiran dan asas peralihan kelanjutan penangguhan penahanan dari tingkat penuntutan ke taraf tingkat pemeriksaan sidang Pengadilan Negeri, ditetapkan secara konsisten dengan uraian terdahulu. Yang ingin disoroti dalam peralihan kelanjutan penangguhan penahanan dari tingkat penuntutan ke taraf pemeriksaan sidang Pengadilan Negeri, lebih dititikberatkan pada persoalan "tata cara" peralihan dan kelanjutan itu sendiri.

Tentang tata cara peralihan kelanjutan penangguhan penahanan dari instansi penuntut umum kepada Pengadilan Negeri, diatur petunjuk pelaksanaannya dalam angka 8 huruf $h$ Lampiran Keputusan Menteri Kehakiman No. M.14 -Pw.07.03/1983.
Tata Cara Pelaksanaan Penangguhan Penahanan Terhadap Tersangka Di Lembaga Kepolisian Berdasarkan KUHAP Dan Peraturan Pelaksanaannya 
Untuk jelasnya angka 8 huruf $\mathrm{h}$ berbunyi sebagai berikut: "Demikian pula halnya apabila berkas perkara oleh penuntut umum telah dilimpahkan kepada pengadilan, sedangkan terdakwa masih dalam status penangguhan penahanan dengan jaminan maka penuntut umum dalam surat pelimpahannya minta kepada Ketua Pengadilan Negeri agar penangguhan penahanan dengan jaminan tetap dilanjutkan". Demikian bunyi petunjuk pelaksanaan dimaksud. Dan bunyi rumusan petunjuk pelaksanaan ini dapat dikemukakan acuan sebagai berikut:

a. Jika penuntut umum berkeinginan bahwa penangguhan penahanan "tidak perlu dilanjutkan" dalam tingkat pemeriksaan Pengadilan Negeri, penuntut umum mengeluarkan "surat perintah penghentian penangguhan" sebelum berkas perkara dikirimkan kepada Pengadilan Negeri. Sejalan dengan pencabutan atau penghentian penangguhan terdakwa dikembalikan dalam status penahanan penuntut umum.

b. Jika penuntut umum menghendaki penangguhan penahanan dilanjutkan dalam tingkat pemeriksaan peng- adilan, dapat mengajukan permintaan kepada Ketua Pengadilan Negeri. Berdasarkan ketentuan ini, betapa sederhana tata cara permintaan peralihan kelanjutan pe-nangguhan penahanan antara penuntut umum dengan pihak pengadilan. Jauh lebih sederhana jika disbanding dengan tata cara peralihan kelanjutan penangguhan penahanan dan penyidik kepada pihak penuntut umum, karena diperikan lebih dulu "konsultasi". Oleh karena itu ada perbedaan tata cara peralihan kelanjutan penangguhan penahanan dari taraf pemeriksaan yang satu dengan tingkat pemeriksaan yang lain. Semestinya lebih baik dianut prinsip yang seragam, yakni tata cara "konsultasi". Tata cara ini lebih efektif dan tidak berbau formalitas serta bersifat lebih terbuka menjalin hubungan kerja sama yang positif yang dapat menghilangkan sikap prasangka dan saling mencurigai.

c. Ketua Pengadilan Negeri dapat menyetujui atau menolak per-mintaan penuntut umum. Dikabul-kan atau tidak permintaan kelanjutan penangguhan penahanan yang diajukan penuntut 
umum dalam surat pelimpahan berkas, sepenuhnya tergantung kepada Ketua Pengadilan Negeri. Dia berwenang menolak atau menyetujui kelanjutan pnangguhan.

d. Penolakan atau persetujuan harus dinyatakan Ketua Pengadilan Negeri secara tegas. Pemyataan penolakan atau persetujuan secara tegas berupa surat, demi untuk kepastian hukum baik bagi pihak penuntut umum maupun bagi pihak terdakwa, keluarganya atau penasihat hukumnya. Malahan kalau Ketua Pengadilan Negeri mendiamkan tanpa penegasan penolakan atau persetujuan maka sikap yang demikian dapat dianggap sebagai persetujuan "secara diam-diam.

e. Jika Ketua Pengadilan Negeri menyampaikan penolakan secara tegas, dengan sendirinya menurut hukum berakhir status hukum penangguhan penahanan. Demikian rasio penolakan tersebut, yakni batal perjanjian penangguhan dan terhenti status penangguhan penahanan yang bersangkutan. Dan sekaligus atas penolakan tersebut Ketua Pengadilan Negeri mengeluarkan "penetapan" penahanan. Karena sejak diterima dan diregister perkara di kepaniteraan pengadil-an, beralih sudah tanggung jawab yuridis atas penahanan terdakwa dan penuntut umum kepada Pengadilan Negeri. Oleh karena itu, jika Ketua Pengadilan Negeri menolak secara tegas permintaan penuntut umum atas kelanjutan status penangguhan penahanan, berarti dia menghendaki supaya terdakwa berada dalam tahanan. Untuk itu dia harus mengeluarkan surat penetapan yang memerintahkan terdakwa supaya ditahan. Dengan keluamya surat penolakan dan penetapan penahanan oleh Ketua Pengadilan Negeri, dengan sendirinya batal dan tidak berkekuatan hukum lagi surat perjanjian dan surat perintah penangguhan penahanan yang dikeluarkan penuntut umum. Jika Ketua Pengadilan Negeri menyetujui permintaan kelanjutan penangguhan surat perjanjian penangguhan surat perintah dan penangguhan yang dibuat penuntut umum harus "diperbarui" atau sekurangkurangnya Pengadilan Negeri membuat "pernyataan bersama" dengan pihak tedakwa, tentang persetujuan mereka atas perjanjian pe-nangguhan 
yang dibuat penuntut umum pada taraf penuntutan. Alasan atas pembaruan ini sama dengan dasar pengkajian yang telah dikemukakan pada waktu membicarakan kelanjutan penangguhan penahanan dari penyidik kepada penuntut umum. (Harahap M. Yahya, 2002 : 228)

\section{e. Pencabutan Penangguhan Pe- nahanan}

Penyidik, penuntut umum, dan hakim berwenang memberikan penangguhan penahanan, sebaiiknya berwenang sewaktu-waktu mencabut kembali penangguhan penahanan. Akan tetapi tentu harus diingat, pencabutan kembali penangguhan tidaklah dapat dilakukan sewenang-wenang. Harus ada dasar "alasan yang layak" mencabut kembali penangguhan. Hal ini diperingatkan Pasal 31 ayat (2) KUHAP, yang memberi pedoman kepada para pejabat yang berwenang, bahwa mereka dapat bertindak melakukan pencabutan penangguhan dalam hal tersangka atau terdakwa "melanggar" syarat-syarat yang ditentukan. Berarti kalau tersangka atau terdakwa tidak melanggar syarat-syarat penangguhan, tidak ada alasan bagi pejabat yang bersangkutan untuk melakukan pencabutan penangguhan.

Penangguhan penahanan dihubungkan dengan Pasal 22 ayat (4) KUHAP, tentang pengurangan masa tahanan dalam putusan hakim, penjelasan Pasal 31 menegaskan: Masa penangguhan penahanan dari seorang tersangka atau terdakwa tidak termasuk masa status tahanan. Berarti masa penangguhan tahanan tidak ikut diperhitungkan dalam pengurangan hukuman yang akan dijatuhkan. Akan tetapi, rasanya penjelasan dan penggarisan Pasal 31 kurang tepat dan kurang sinkron dengan pengurangan tahanan yang ditentukan sendiri dalam Pasal 22 ayat (5), yang menentukan penahanan kota pengurangannya $1 / 5$ dari jumlah lamanya waktu penahanan sedang untuk penahanan rumah dikurangi $1 / 3$ dari jumlah lamanya dalam tahanan. Sebenamya penjelasan Pasal 31 kurang tepat dan tidak sinkron 40 dengan Pasal 22 ayat (5)? Karena kalimat pertama penjelasan Pasal 31 itu sendiri, yang berbunyi:"Yang dimaksud dengan syarat yang ditentukan ialah wajib lapor, tidak keluar rumah atau keluar kota". Mempunyai pengertian sama dengan
Tata Cara Pelaksanaan Penangguhan

Penahanan Terhadap Tersangka Di Lembaga Kepolisian Berdasarkan KUHAP Dan Peraturan Pelaksanaannya 
penangguhan penahanan dengan syarat tidak boleh keluar rumah atau keluar kota. Dengan adanya syarat penangguhan tidak boleh keluar kota, pada hakikatnya tidak lain daripada "pengalihan" jenis penahanan, atau sama dengan jenis penahanan rumah ataupun jenis penahanan kota.

\section{PENUTUP}

Permohonan Penangguhan Penahanan biasanya dilatarbelakangi adanya kesepakatan antara kedua belah pihak baik pelapor maupun terlapor. Kesepakatan yang dilakukan dengan disaksikan oleh instansi yang berwenang. Selain itu delik yang terjadi berupa delik aduan sehingga memungkinkan dihentikan oleh pihak pengadu. Hal ini sesuai pengertian pengaduan yang diatur dalam pasal 1 angka 25 KUHAP. Dengan demikian terhadap perkara delik aduan dimungkinkan terjadi kesepakatan damai pihak pelaku dan pihak korban sehingga kondisi tersebut sebagai salah satu latar belakang terjadinya permohonan penangguhan penahanan. Selain itu di lembaga menerima permohonan penangguhan penahanan dengan latar belakang antara lain : a. tersangka menderita sakit/ mengalami gengguan jiwa;

b. pertimbangan kemanusiaan;

c. adanya jaminan/penjamin.

Penahanan atas diri tersangka/ terdakwa dapat ditangguhkan pelaksanaannya oleh Penyidik, Penuntut Umum atau Hakim yang menahannya sesuai dengan kewenangan masingmasing. Penangguhan penahanan itu dilakukan dengan jaminan uang atau orang atau tanpa jaminan sama sekali (Pasal 31 KUHAP).

\section{DAFTAR PUSTAKA}

And Hamzah, Hukum Acara Pidana di Indonesia, Sinar Grafika, Jakarta, 2000.

Butham Burgin At, Penelitian Sosial, Airlangga University Press, Surabaya, 2001

Djoko Prakoso, kedudukan Justisiabel Di Dalam KUHAP, Ghalia Indonesia. Jakarta, 1986.

Darwan Prinst, Hukum Acara Pidana Dalam Praktek, Djambatan, Jakarta, 2002.

Harahap, M. Yahya, Pembahasan Permasalahan dan Penerapan KUHAP, Sinar Grafika, Jakarta. 2002.
Tata Cara Pelaksanaan Penangguhan Penahanan Terhadap Tersangka Di Lembaga Kepolisian Berdasarkan KUHAP Dan Peraturan Pelaksanaannya 
P.A.F. Lamintang, KUHAP Dengan Pembahasan Secara Juridis Menurut Yurisprudensi dan IImu Pengetahuan Hukum Pidana, Sinar Buru, Bandung, 1986.

Ah.Daribuan, Luhut M.P., Hukum Acara Pidana Satu Kompilasi Ketentuanketentuan KUHAP Serta Dilengkapi Dengan Hukum Intemasional Yang Relevan, Djambatan, Jakarta, 2002.

Hanitija Soemitro, Metodologi Penelitian Hukum dan Jurimetri, Ghalia Indonesia, Semarang, 1988.
Soekanto, Pengantar Penelitian Hukum, Universitas Indonesia, Press) Jakarta, 1986.

Asas-asas Hukum Pidana Indonesia dan Penerapannya, ARHACA Petehaem, Jakarta, 1989.

Sanipiah Faisal, Penelitian-Kualitatif : Dasar-dasar dan Aplikasi, Yayasan Asih, Malang, 1990

Winarno Surakhmad, Pengantar Penelitian Ilmiah Dasar, Metode, Teknik, Bandung, 1982. 